\title{
Artículo especial: Obras maestras del arte universal y la medicina: En busca del tiempo perdido (II) de Marcel Proust (1871 -1922)
}

Universal art masterpieces and medicine: In search of lost time (II) by Marcel Proust (1871-1922)

Carlos G. Musso

Musso CG. En busca del tiempo perdido (II) de Marcel Proust (1871 -1922). Evid Act Pract Ambul.2014 17(4). Oct-Dic 135.

El estilo de Proust es de un inconcebible aburrimiento asociado al éxtasis más extremo que imaginarse pueda Henry James

\section{Marcel Proust: su enfermedad y arte}

Enfermo de asma desde los ocho años de edad, su afección se agrava tras la muerte de sus padres, obligándolo a quedarse confinado a su departamento del bulevar Haussmann (Paris). Es entonces que, con más de treinta años de edad, y desolado por los estragos que el tiempo le produce a personas y cosas, se aboca a escribir su monumental novela (siete tomos) de carácter autobiográfico (En busca del tiempo perdido), con la cual logra recuperar su pasado y obtener la inmortalidad. Su estilo de escritura, caracterizado por frases gigantescas, pletóricas de oraciones subordinadas, pareciera perseguir el objetivo de detener el paso del tiempo, reflejar el tedio de su confinamiento, y hacerle experimentar al lector la disnea a la que su enfermedad bronquial lo sometía. Asimismo, imaginariamente, el aire y el tiempo que sus lectores consumen en la lectura y asimilación de su obra (es decir, en él), logran compensar (recuperar) el aire y el tiempo perdidos por su enfermedad.

\section{Ejemplo frase proustiana (452 palabras). "La prisionera" (tomo V)}

"Sofá surgido del sueño entre los sillones nuevos y muy reales, unas sillas pequeñas tapizadas de seda rosa, tapete brochado a juego elevado a la dignidad de persona desde el momento en que, como una persona, tenía un pasado, una memoria, conservando en la sombra fría del salón del Quai Conti el halo de los rayos de sol que entraban por las ventanas de la Rue Motalivet (a la hora que él conocía tan bien como la propia madame Verdurin) y por las encristaladas puertas de La Raspèhere, adonde la habían llevado y desde donde miraba todo el día, más allá del florido jardín, el profundo valle, mientras llegaba la hora de que Cottard y el violinista jugaran su par- tida; ramo de violetas y de pensamientos al pastel, regalo de un gran amigo va muerto, único fragmento superviviente de una vida desaparecida sin dejar huella, resumen de un gran talento y de una larga amistad, recuerdo de su mirada atenta y dulce, de su bella mano llena y triste cuando pintaba; un arsenal bonito, desorden de los regalos de los fieles que siguió por doquier a la dueña de la casa y que acabó por adquirir la marca y la fijeza de un rasgo de carácter, de una línea del destino; profusión de ramos de flores, de cajas de bombones que, aquí como allí, sistematizada su expansión con arreglo a un modo de floración idéntico: curiosa interpolación de los objetos singulares y superfluos que aún parece salir de la caja en la que fueron ofrecidos y que siguen siendo toda la vida lo que en su origen fueron, regalos de Año Nuevo, en fin, todos esos objetos que no sabríamos diferenciar de los demás, pero que para Brichot, veterano de las fiestas de los Verdurin, tenían esa pátina, ese aterciopelado de las cosas a las que añade su doble espiritual, dándoles así una especie de profundidad; todo esto, disperso, hacía cantar para él, como teclas sonoras que despertaran en su corazón semejanzas amadas, reminiscencias confusas y que en el salón mismo, muy actual, donde ponían su toque acá y allá, defininían, delimitaban muebles y tapices, como lo hace en un día claro un cuadrado de sol seccionando la atmósfera, los tapices y de un cojín a un jarrón, de un taburete al rastro de un perfume, perseguían con un modo de iluminación en el que predominaban los colores, esculpían, evocaban, espiritualizaban, daban vida a una forma que era como la figura ideal, inmanente en sus viviendas sucesivas, del salón de los Verdurin"

Concluimos que la lectura de En busca del tiempo perdido de Marcel Proust brinda una oportunidad excepcional para experimentar los síntomas psíquicos y físicos padecidos por un paciente asmático grave.

\section{Referencias}

1. Proust M. La prisionera. En busca del tiempo perdido. Buenos Aires. CS Ediciones. 2006

2. Leherer J. Poust y la neurociencia. Barcelona. Paidós. 2010

3. Beutler M. Proust. Los hombres de la historia. Buenos Aires. Centyro Editor de América

Latina. 1986

4. Ruiz R. Le temps retrouvé 1999. (film)

5. Musso CG. En busca del tiempo perdido de Marcel Proust (1871 -1922). Evid Act Pract Ambul. 2012;15(2):58. Disponible en URL: http://www.evidencia.org/files/583d5a30bd3697e274906a4fd8a7b776.pdf 